UDC $621.039,61: 533.95: 621.313 .4: 621.311 .29$.

$07: 681.3 .02$

\title{
$0.5 \mathrm{MJ}$ 超電導パルスマグネットの特性と その制御システム
}

\begin{tabular}{|c|c|c|c|}
\hline 正 員 & 村 & 上 & 吉 繁 \\
\hline 正 員 & 伊 & 瀬 & 敏 \\
\hline 会 & 山 & 本 & 純 \\
\hline 面 & & & 韵一 \\
\hline
\end{tabular}

\section{1. まえがき}

超電導パルスマグネットの研究は，我が国では 1970 年代から盛んに行なわれた。その目的は，磁界閜込め 形核融合㛎のプラズマ加熱用パルスコイルを超電望マ グネットとして開発するたかの基礎研究を行なうこと ですったば。コイルのパルス電流によって核融合弱の 磁界を $10 \mathrm{~T} / \mathrm{s}$ 以上の速度でパルス状に変化させれば， プラズマ中に管磁誘導に上って䉓流を誘起し，その才 一ム損失によってプラズマを加熱するととができる。

一方では，パルスマグネットに眝蔵される電気エネ ルギーを急速に辛放電することによって，電力䒺統の 安定化が有效に行なえるととが最近の研究で明らかに なった ${ }^{(2)(3)}$ 。乙の場合には，電源の 1 サイクル以内に 有効電力 $(P)$ および無効需力 $(Q)$ の充放電を制御でき る性能が系統に古ける電力潮流之電Eの变動の神償に 活用される(4)-(6)。

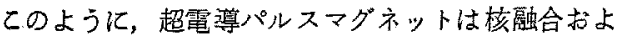
び電力眝藏はどエネルギー技街への店用が期待され， 各方面でマグネットの特性と応用のためのシスデム技 䓋の研究がなされている。パルスマグネットの磁界変 化速度については，アメリカのロスアラモスおよびア ルゴン又研究所(7)，我加国で日本原子力研究所，東 艺などで磁界の增加肪よび咸少の両方について変化速

Characteristics and Control Systern of $0.5 \mathrm{MJ}$ Superconducting Pulsed Magnet. By Yoshishige Murakami, Member, Toshifumi Tse, Member (Eaculty of Engineering, Osaka University), Junya Yamamoto, Non-member (Low Temperature Center, Osaka University) \& Kiichiro Tsuji, Member (Faculty of Engineering, Osaka University).

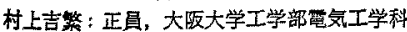

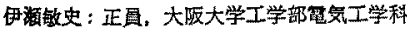

山本神也 : 非会是, 大防大学低温せンター

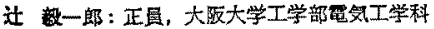

論 文

$59-B 79$
度 $6 \mathrm{~T} / \mathrm{s}$ 以上店得ている。最近では，この速度は名古 琹大学プラズマ研究所，日本大学，三菱電機および電 子技莸総合研究所の共阔研究により $200 \mathrm{~T} / \mathrm{s}$ 亿到達し た ${ }^{(8)}$ 。これらの成果は，パルス駆動に対して交流損失 が少なく，熱除去特性の俇れた導体上コイル棈造につ いてのこれまでの多くの技衡蓄皘化直うものて，磁界 変化速度について初期の目䅺に到達しているといえ Љ。

今後は，このようなパルスマグネットを核融合や電 力系統などのエネルギ一発生と利用システムに扎いて 活用するための運用方式と，乙れを荛付けるための制 御システムのソフトウェアとハードウェアを開発し， 超電導技街のエネルギ一技術への奏用化を图らね标な らない。大阪大学超電筫工学実験センターでも，0.5 MJ のパルスマグネットを開発し，マグネットの特性 上，その制鹳システムについて実験的研究を重㸚てい る。これまでは，多くの研究が線材構成や交流損失の 評価などマグネットの構成と特性を中心課題にしてき to。

これに対し，とこではシステム技術の立場でマグネ ット走等価回路で表現して動特性を同定し，直接ディ ジタル制御方式を薏用することにより高精度で最大磁 界において6.1 T/s の高速度のマグネット電流制御特 性を得たこと，充放暼やクウェンチ時のモード制御に 执いて，マグネット之雷源に障害を与えない上うな主 回路のシーケンス制御方式を完成したこ上を还へる。 また、マグネットの線材と構成においてす適切な配慮 を施した結果，交流損失が少なく、高電流密度に和い ても安定性の高い通電特性が得られ，マグネット技㧓 に新しい進歩が得られたととを報告する。 


\section{2. $0.5 \mathrm{MJ}$ パルスマグネット}

超電導パルスマグネットを設計する上き考慮を払わ 㭺ならない事項として次の諸点があげられる。

(1) エネルギー眝蔵效率を高め，常電導転移に対 する安定性を確保するために，マグネットのパルス駆 動時に尔ける交流損失をできるだけ少なくすること。

（2）交流損失による熱の発生を除去するよう冷却 媒体の通路を十分任設省ると。

（3）繰り返しパルス駆動によるコイル椣造のゆる みについて対策を施すこと。また，楾材や構造材料の 繰返し応力に上る疲学を適切に考虑して, 耐用限界を 設定するとと。

$0.5 \mathrm{MJ}$ パルスマグネットの開発に招いては。 $5 \mathrm{~T} / \mathrm{s}$ (最大磁界 $6.1 \mathrm{~T} / \mathrm{s}$ ) の磁界の增加率求よび減少率を目 標にした。この值を目指すため，上記の諸点について 上下の上うな対策を施した。

(i) パルスマグネットの線材については，我が国 においててれまで图1亿示すような， $\mathrm{NbTi} / \mathrm{Cu} / \mathrm{CuNi}$ の 3 層構造フィラメントを基本要素之する複合多心線 構成法の技術が育成されてきた(10)。乙のマグネット でも，フィラメント構造は同し 3 層構造 (直徍 $34 \mu \mathrm{m}$ ) で，更に新いい試みとして，フィラメント216本加ら なる素線 (ストランド) 外皮す $\mathrm{CuNi}$ 合金で被覆する ととにより，パルス駆動時の素線間の結合電流を低減 する構成学試みた。金属巻模の場合のうず電流を考慮 して，コイルの巻枠はガラスエポキシ材料 (G-11) 製作した。

（ii）コイルを 14 層ダブルパンケーキ巻線構造と して，層間にガラス強化プラスチックスペーサを挿入 して半径方向に液体へリウムが流動する冷却チャネル を設けた。また，巻枠表面には垂直にへリウム流路用 满を掘った。更にケーブル表面積の $40 \%$ は液体へリ ウムに直接触れるように間隔をありて絶縁テープを巻

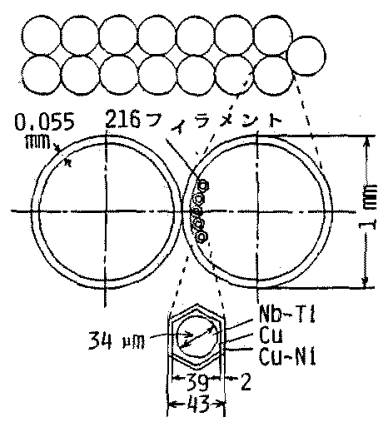

因 $10.5 \mathrm{MJ}$ マグネットの線材

Fig. 1. Cable structure of $0.5 \mathrm{MJ}$ magnet.
表 $1 \quad 0.5 \mathrm{MJ}$ パルスマグネットのパラメータ

Table 1. Parameter values of $0.5 \mathrm{MJ}$ pulsed magnet.

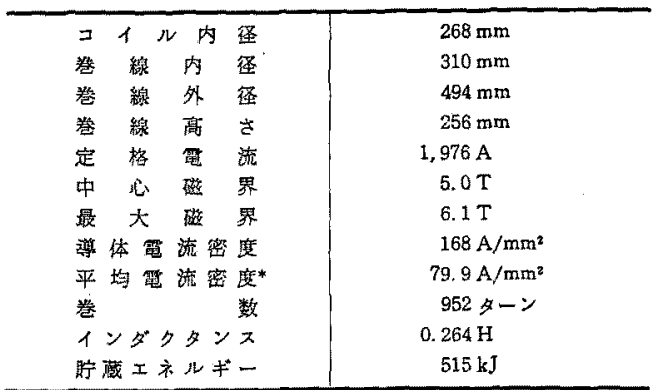

*: 全アンペターンとコイル全断面租の比

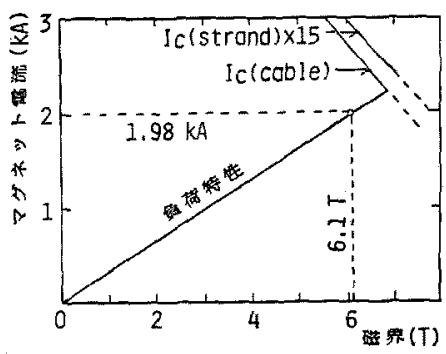

図 2 マグネットケーブルの臨界電流々負荷特性

Fig. 2. Critical current and load characteristic of the magnet cable.

いた。

（前）また，强固なコイル構造が得ら机るように， コイル巻線加工に掠いて，適切な張力を加えるように した。更に巻線の表面には，ガラスファイババンド (GFRP) を巻き，半径方向の線材ずれを押さえ込むよ うにした。

とのようにして高い電流密度においてす超䉓導を十 分安定に維持できるコイルとなった。このととは，交 流損失の原因上なる安定化導体の断面積が少なくて， しかむ直流通電耴いても安定なコイルであることを 意咮している(11)(12)。

表1に示した導体電流密度 $168 \mathrm{~A} / \mathrm{mm}^{2}$ 滈い水準 のものである。また超電薄ケーブルの臨罳電流值住， $6.1 \mathrm{~T}$ に扔いて 2,650 A である。ケーブルは 15 本 の素線をより合せて作られているが，ケーブルの臨界 電流値は素線の臨界電流値の 15 倍の $89 \%$ であり， ケーブルの整形加工工程において特性の劣化があった ととを意味している。磁界と臨界電流，抽よび磁界と 電流との間の复荷特性の関係を四 2 に示す。

\section{3. $0.5 \mathrm{MJ}$ マグネットの動特性}

〈3.1〉 マゲネットの等洒回路パラメータの推定方 
法＼cjkstart超電導マグネットの雪流を高精度で制御するた かには，制御対象の動特性を正確によらえなくてはな らない。筆者のこれまでの研究では状㑷ベクトルフィ

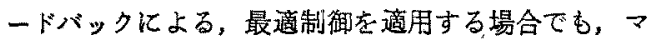
グネットを抵抗 (R) とインダクタンス $(L)$ の直列回路 て簡単に表現しても，との回路パラメータを適切に与 えれば満足できる結果が得られている(13)(14)。

しかし，とれらのバラメータは，マグネットの通電 電流值 $\left(I_{S M}\right)$ とその時間的な变化率 $\left(\dot{I}_{S M}\right)$ によって 変化すると考え极ばならないそしで、マグネットパ ラメータを定めるために次の上うに実際的な方法を探 用している。

(1) Lはマグネットの設計値で与え， $R$ は変珐 器漏れインダクタンスおよび配線などの担抗分によっ て生じるサイリスタ電力変換装置の正流側の電王降下 を与える等価抵抗倠上する。との值は，变圧器のイン ダクタンスの設計值と，その他の抵抗分の推定値に上 って定める。

（2）（1）で与えた回路パラメータを中心记した数 種のパラメータ值によってマグネット電流の制御特㙫 をシミュレーションする。その結果と实際の制御特性 とを比較して最も適当なパラメータ值に修正する。

(3) 別に，不䂓則電压入力をマグネットに与え， 出力としてマグネット電流を記録して入出力特性から 動特性を推定する。この結果により（1)および（2) の回路パラメータの旁付けを得る。

〈3.2〉 入出力特性によるマグネットの等価回路パ ラメータの推定＼cjkstart超電導マグネットに不規則波形の 電压 $V_{S M}$ を入力して与え，その出力としてのマグ ネット電流 ISMとの関係を線形離散值系(パルス伝達 関数) として表現する。更にこの系の方程式から等価 回路を推定する方法をこれまでに導いた(14)。0.5 MJ マグネットの重特性の推定にも，との方法を適用し

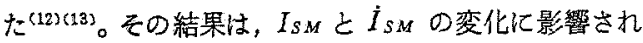
大きな変動がある。パルス伝達関数 $G_{S M}(z)=I_{S M}(z) /$ $V_{S M}(z)$ 加ら図30上うな等価回路のパラメータを推 定した。等洒的には $\left(R_{1}-L_{1}\right)$ に主に電流加流れ，動特

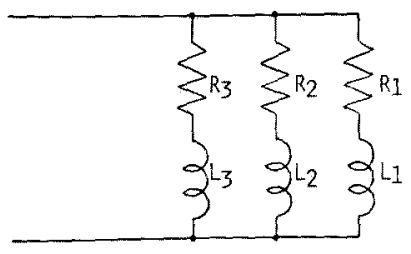

図了マグネット等価回路

Fig. 3. Equivalent circuit of the superconducting magnet.

昭 $59-10$
性の回路表現むこれだけで十分である。(R2-L2)（R $\left.-L_{3}\right) \cdots$ 枝は㝬生的な素子 (parasitic elements) で、 グネット主回路と相互誘導で結合し，マグネット線材 中やクライオスタット金属中に誘起されるうず電流に よる損失と磁束を主回路側撸算して表現した等価回 路素子と考えられ，GSM $(z)$ の部分分数展開各項をえ

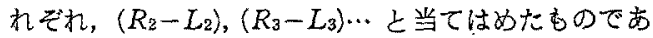
る。 $\left(R_{3}-L_{3}\right) \cdots \omega$ 全体の電流への寄与は無視できる程 度である。 $I_{S M}$ の変域が大きく，かつ $I_{S M}$ が大きい ほど， $L_{1}$ は設計值 $(0.264 \mathrm{H})$ 上り小さくなる傾问加 ある。電流波形化尗りハラメー夕蛙 $R_{1}=0.01 \sim 0.05$ $\Omega, L_{1}=0.18 \sim 0.27 \mathrm{H}, R_{2}=5 \sim 28 \Omega, L_{2}=0.02 \sim 0.7$ $H$ の範囲で変化している。図 4 に測定された $V_{S M}$ お よび $I_{S M}$ と，それから埒出された GSM(z) に基づい て ISM を推定した結果を示している。ISM の湘定波 形乙推定した $\hat{I}_{S M}$ はよく一致しており，変動する動 特性のパラメータがよく追䟢されている。

以上述へたように，動特性のパラメータの変動が大 きい上ころから，正確な制御に仿パラメー夕を道応せ しめるようなモデル規笎適芯制御系を探用すべさと を示唆している。また， $\dot{I}_{S M}$ が大きいときに 少する傾向は，ステンレス鋼製クライオスタットに流 れるうす電流によりコイル全体の磁界の急速な変化が 妨げられる傾向龙わしていると考えられる。

图 4 の波形に上る推定結果加ら， $R_{2}=28.2 \Omega, L_{2}=$ $0.205 \mathrm{H}$ として，1.3 秋の間に三角形状に電流をゼロ から 1,200A まで立ち上げ，再びゼロに杘す駆動をす る場合の交流損失走計算すると，1パルスあたり， 10,995丁となる。一方，との計算とは別にマグネット だけの交流損失を計算すると次のようになる。

マグネットの交流損失は，フィラメント間の結合電 流化よる結合損失 $W_{p}$ とヒステリシス强失 $W_{h}$ とか らなる。まず，単位体積あたりの結合損失 $w_{p}$ は，

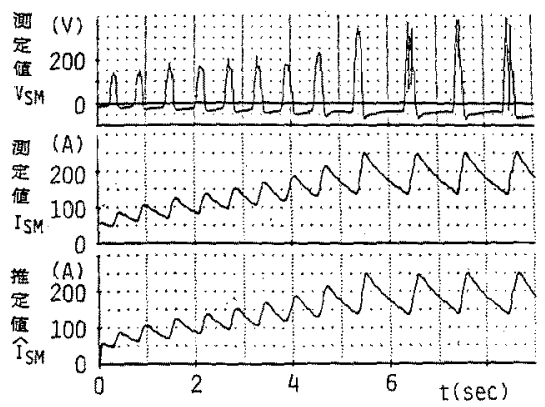

图 4 不規則入力八出力波形によるマグネット 動特性の推定

Fig. 4. Identification of the magnet dynamics using random input/output waveforms. 


$$
w_{p}=2\left(B_{m}^{2} / 2 \mu_{0}\right) \cdot\left(2 \tau_{0} / t_{e}\right)\left(\mathrm{J} / \mathrm{m}^{3}\right)
$$

で与えられる(20)(17)。ここで，では結合損失の等価時

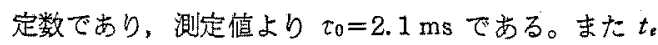
岎電流变化平均時間で, 電流立上り時間 $t_{u}$, 電流減少

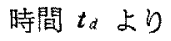

$$
\frac{2}{t_{e}}=\frac{1}{t_{u t}}+\frac{1}{t_{d}}
$$

とする。 $t_{u}=t_{d}=0.65 \mathrm{~s}$ より $t_{s}=0.65 \mathrm{~s}$ となる。 1,200 A での磁界を $B_{m}=3.70 \mathrm{~T}$ とすると,

$$
w_{p}=7.06 \times 10^{4}\left(\mathrm{~J} / \mathrm{m}^{3}\right)
$$

となる。マグネット全体の結合損失は，マグネットの 体䖽を $V\left(V=(\pi / 4) \cdot\left(0.494^{2}-0.31^{2}\right) \times 0.255 \mathrm{~m}^{3}\right)$ とし $\tau$

$$
W_{p}=(1 / 3) \omega_{p} V=697.5(\mathrm{~J})
$$

之算出される。次化，ヒステリシス損失蛘位長あた b

$$
P_{h}=2 J_{c} / 3 \pi \cdot d \dot{B}\left\{1+\left(I_{t} / I_{c}\right)^{2}\right\} A_{s c}(\mathrm{~W} / \mathrm{m})
$$

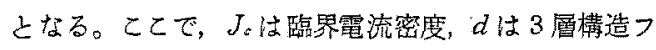

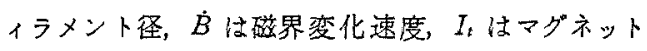
ケーブル通電電流（定格値），。はマグネットケーブ ル臨界電流，As は はケーブル中の超電導導体䉼面積で それぞれ， $J_{c}=2.2 \times 10^{9} \mathrm{~A} / \mathrm{m}^{2}(4 \mathrm{~T}$ において)，d=40 $\times 10^{-6} \mathrm{~m}, \dot{B}=6 \mathrm{~T} / \mathrm{s}, I_{t}=1,920 \mathrm{~A}, I_{c}=3,000 \mathrm{~A}, A_{s c}$ $=\left\{\left(40 \times 10^{-6}\right)^{2} \pi / 4\right\} \times 210 \times 15=3.96 \times 10^{-6} \mathrm{~m}^{2}$ とすれば

$$
P_{h}=0.625(\mathrm{~W} / \mathrm{m})
$$

となる。コイル長 $l(1,358 \mathrm{~m})$ 几わたって1パルス期 間 $\left(t_{u}+t_{d}=1.3 \mathrm{~s}\right)$ 亿求壮るヒステリシス損失を求める ¿,

$$
W_{h}=(1 / 2) P_{h} l\left(t_{u}+t_{d}\right)=551.7(\mathrm{~J})
$$

となる。徉って，マグネットの交流損失は，

$$
W_{h}+W_{p}=1,249(\mathrm{~J})
$$

となる。ここで（3)式における(1/3)，杖よひ（5) 式における(1/2) は経駼的な重み係数である。てのよ うに，マグネット本体の交流損失は，貯蔵エネルギー $500 \mathrm{~kJ} の 0.25 \%$ に過ぎず極めて少ないといえる。等 価回路の $R_{2}$ には，マグネット本体の交流損失上クラ イオスタットに誘起するうず電流による損失す含まれ ている。推定した $R_{2}$ の值倸より求的た推失 $(10,995$ J)の大部分はクライオスタット中の損失によるもので ある。

次に，ヘリウム蒸発量加らパルス駆動時の損失を推 定すると，1パルスあたり 6,000Jとなり，等価回路 より推定した值よりは小さい。その理由次のように 洘えれる。
交流損失に上る液体へリウム蒸発量は、マグネット 本体とステンレス銅製クライオスタット内壁のヘリウ ム液面レベルまでの交流損失によって生じている。と

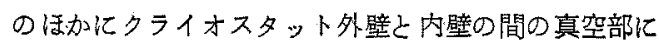
液体窒素温度の銅製の輻射熱しゃへい槽吕あり，この 部分にむ交流損失を生じるが，液体へリウムの蒸発に は関係しない。等価回路より推定した損失はこの損失 む加えたるのとなっている。

\section{4. 超電導マグネットシステム}

大形の超電導マグネットを高い信賴性のもとに活用 するには，超電導マグネットを運用する技術としての 超電導マグネットシステム技術を確立していか极ばな らない。マグネットシステム菠術としては，

(1) 電力系統に招いてマグネットを効果的に運用 する上位レベルの方策

そのもとでの下位レベルの制御技術として，

（2）マグネットの保護動作および永久電流運転な どに件なうモード制御

（3）電流お上び電力の高精度・高速度制御手法 がなくてはならない。 $0.5 \mathrm{MJ}$ マグネットでは，上記 の(2)と(3)のシステム技術の原形として図5のよう なシステムを構成した(16)。

主回路には，保護抵抗の投入・短絡用に $S_{1}$, マグ ネットの短絡用に $S_{2}$, 電源投入・しp断用に $S_{3}$, 変 換装置直流出力の直列・並列接続用に $S_{4}$ の各種スイ ッチがある。これらのスイッチはシーケンス制御装置 のむとに执かれ、マグネット運転の各種モード，すな

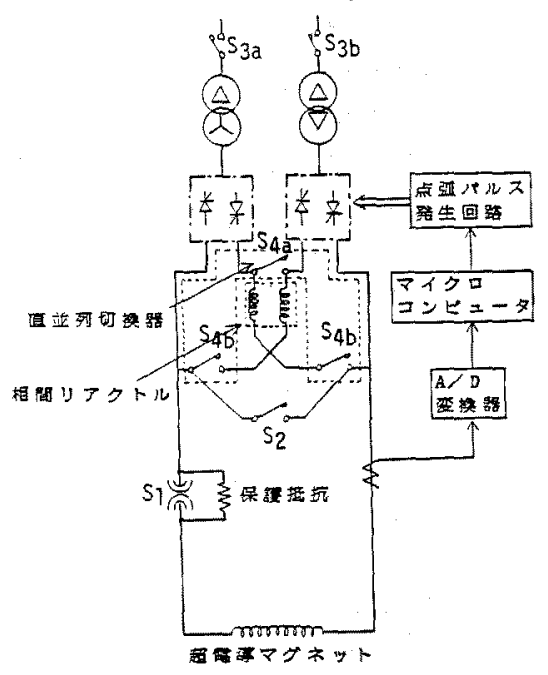

困 5 マグネットシステムの構成

Fig. 5. Configuration of the magnet system. 
わち充放電，永久電流，異常状態における保護などの モード制御が行なわれる。

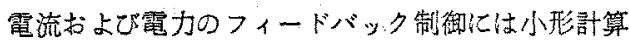
譏 LSI-11/23によよる直接ディジタル制御が適用され る。以下では，直接ディジタル制御による電流制御に 引綵きモード制制について述べる。

\section{5. 直接ディジタル制御による超電導マグ ネット電流の高速度制御}

〈5.1〉制御系の構成 これまでに小形マグネッ $卜(3 \mathrm{~kJ})$ について，三相ブリッジ接続サイリスタ電力 変換装置の，直接ブィジタル制御方式在開発してき た ${ }^{(13)}$ 。乙の成果志用して，0.5MJ マグネットにつ いて図5のような小形計算機 LSI-11/23による制御 系索構成し，各種の制御方式索試みた。变換装置の1 基南たり直流側出力は $500 \mathrm{~V} / 1,000 \mathrm{~A}$ で，2 基の接続

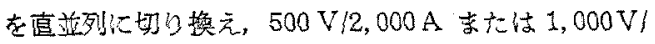
$1,000 \mathrm{~A}$ の出力を得る。亚列遭転時には電流を 2 台の 変換装置で均等化分担するように相間りアクトルを插 スしている。

マグネット電流の、フィードバック制御を行なう場 合, 乙の電流は, 直流電流变換器 (DCCT) に上って電 压值江変換されて梌出される。三相交流電源の相電匤

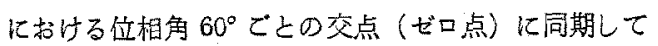
電流值在 A-D 変換（分解能 10 ビット，変換時間 60 山s）する。計算機仿ディジタル化された電流量を取り 込んで制御演算を実行し，えの結果得られる変換装置 の出力電在値の逆余弦演算加ら点弧角 $\alpha$ をディジタ ル量しして決定し，その值をバッファストレジレジス タへ出力する。三相交流雷压の交点 (ゼロ点)が検出 されるとパルス分配器により，点弧すべきサイリスタ のダウンカンタに点㼋角が置数される。カウンタは $480 \mathrm{kHz}$ のクロックにより隇算し，ゼロに至ればトリ ガパルスを発生する。半サイクル $\left(180^{\circ}\right)$ 亿相当するデ イジタル量蛙 4,000である。

〈5.2〉最適レギュレータ（LQI）制御状態べタ トルフィードバックにより，次の制御采のいずれを害 現することができる。

（1）制御系の固有檤を指定通りに設定する。

（2） 2 采皘分形の評価関数を最小化する (LQI)。

（3）非干涉制御系，あるいは動的分割系在構成す る。

超電導マグネット制御系の制御量法，電流値(1出 力）または，有效扔よび無效電力（2出力）である。 電流値制御は 1 入力(基等電流)/1出力(マグネット䉓 流) 系であるから，非干渉の考慮は不必要で，(1)に
属する有限整定制御呫よび(2)のLQI 制御の適用を 検討した(18)。

有限整定制御仁おいては，系の次数nのステップ数 で基準值仙整定せし的る制御之なるが，操作量が過大 になる。また，系の動特性のパラメータ変動に対して 感度を低くするよう䚺調整パラメータを別て尊入する

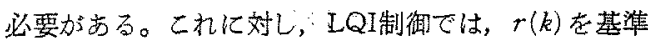
大力, $y(k)$ を出力， $\omega$ を重媇数として，評洒関数を

$$
\begin{aligned}
J= & \sum_{k=0}^{\infty}\left\{(r(k)-y(k))^{2}+\omega(\Delta u(k))^{2}\right\}, \\
& \Delta u(k)=u(k)-u(k-1)
\end{aligned}
$$

によって与えれば， 性変動汇対する感度を下げ，プラントとモデルの動特 性の不一致俘よる制御特性の劣化老緩和，適当な制 御特性が得られるので，LQI制御老適用することにし た。

超電尊マグネットの動特性は，第3章で述べた考察 加ら，(R-L)直列回路によって近似している。更に 1 サンプル期間 $T$ の間同一点弧角が出力されるので, 電力変換装置出力電圧を期間 $T$ のサンプルホールド と利得 $K_{1}$ で近似し，演算より計算機出力代至るまで の期間をむだ時間 $T_{1}$ で表わしている。てれらの伝達 関数とマグネット動特性を接続した構成を図6のよう に制御対象（プラント）の罝特性としている。てのプ ラントの動特性はパルス伝達関数

$$
\begin{aligned}
G_{p}(z) & =Z\left[K_{1} e^{-T_{1} s} \cdot \frac{1-e^{-T s}}{s} \cdot \frac{1}{R+s L}\right] \\
& =g_{1} Z^{-1}+g_{2} Z^{-2}+g_{3} Z^{-3} /\left(1-P Z^{-1}\right)
\end{aligned}
$$

によって表わす(13)。このパルス伀達関数を，状態方程 式によって表わせば，状龍べクトル $x=\left[\begin{array}{lll}x_{1} & x_{2} & x_{3}\end{array}\right]^{T}$ に対する最適フィードバック利得 $\boldsymbol{K}=\left(\begin{array}{ll}k_{1} & k_{2} k_{3}\end{array}\right\}$ およ び積分器利得 $K_{l}$ は,リカッチ方程式の解として求め bれ， $k_{1}=0, k_{2}=K_{1}$ 亡 $k_{3}$ 少得られる。乙てで， $x_{1}$ $(k)=y(k)$ である。また，図6に术いて $K_{2}$ は，電流 検出端である $\mathrm{DCCT}$ と $\mathrm{A}-\mathrm{D}$ 变換器の特性をあわせ て利得 $K_{2}$ で近似たたのである。

観測器においては，図7にみるように整定べクトル $\hat{x}_{0}(k)$ 観测值 $y(k)$ によって修正し，状態ベクトル の推定檤 $\hat{\boldsymbol{x}}(k)$ が得られ，己机に利得 $\boldsymbol{K}$ を乗じて，

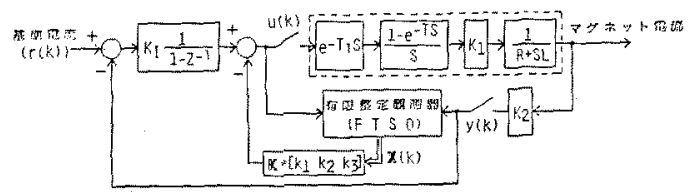

図 6 制御系のブロック線図

Fig. 6. Block diagram of the control system. 


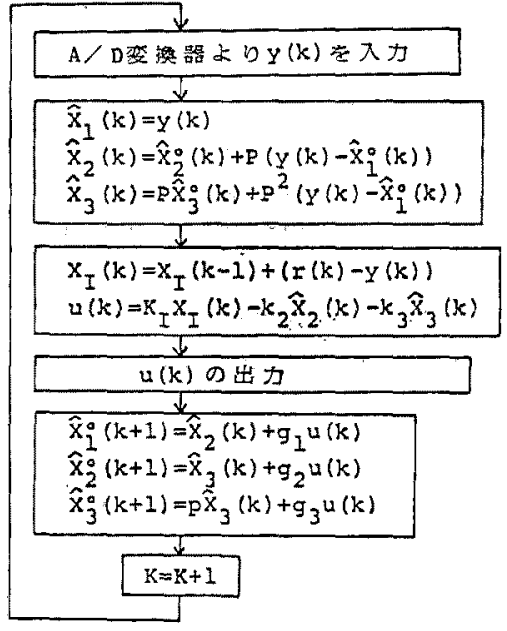

図 7 LQI 制期のアルゴリズム

Fig. 7. Algorithm of LQI control.

表 2 シミュレーションで用いたパラメータ

Table 2. Parameter values for simulation.

\begin{tabular}{c|c}
\hline$L$ & $0.264 \mathrm{H}$ \\
$R$ & $0.04 \Omega$ \\
$T$ & $16.7 \mathrm{~ms}$ \\
$T_{1}$ & $5.56 \mathrm{~ms}$ \\
$K_{1}$ & $621 / 4,000 \mathrm{~V} / \mathrm{digit}$ \\
$K_{2}$ & $1,024 / 3,000 \mathrm{digit} / \mathrm{A}$ \\
\hline
\end{tabular}

$u(k)$ を定めている。

〈5.3〉制御特性 LQI 制御に掠いて考慮すべき 事項住，

(1) 操作量の変化 $\Delta u(k)$ の重み $\omega$

（2）制御対象動特性のパラメータ変動

(3) A-D 変換器量子化䛠差の影響

である。表2に示すような各パラメー夕を与えて制御 系のシミュレーションを行なった結果を図8に示して いる。（a 〜（c）の版に $\omega$ を小にするほよ゙，基準入 力に正確に追徉するようになるが，電流検出の量子化 誤差の影響でマグネット電正にこまかな振動がみられ るようにはる。また，モデルバラメータをプラントパ ラメータと異なる $L=0.2 \mathrm{H}, R=0.08 \Omega$ と与えた結 果は (d)図に示している。契験です同様の傾向が見ら れるので， $\omega=0.05$ を適当な重みしして設定し，繰返 しパルス励磁と単一パルス励磁について得られた特性 を図9に示す。とのパルスマグネットの開発に就りる 目標の一つである劯磁速度 $5 \mathrm{~T} / \mathrm{s}$ が電流変化率 1,976 $\mathrm{A} / \mathrm{s}$ の正確な電流制御によって達成されている。

\section{6. 超電導マグネットのモード制御と保護}

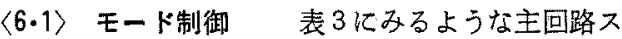
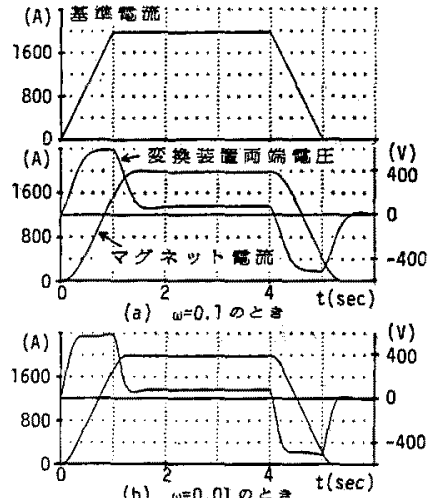

(b) $\omega=0.010$ ह $t(\mathrm{sec})$
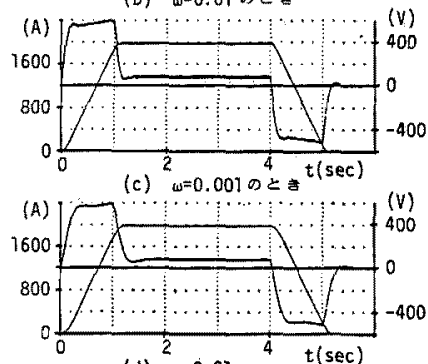

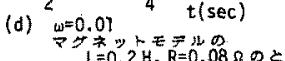

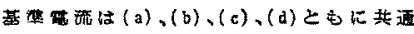

図 8 制御特性のシミュレーション結果

Fig. 8. Simulated performance of the control algorithm.

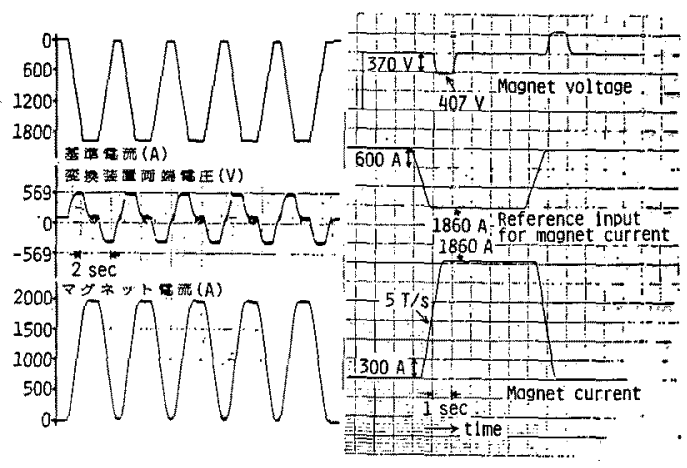

(a)

(b)

図 9 (a)連続パルス励磁，および(b)単一 パルス励磁の実験結果

Fig. 9. Experimental results of, (a) repeated pulsed operation, and (b) single pulsed operation.

イッチの關閶の組命せによってモード制御を行なう。 サイリスタ短絡モード(スルーモード) は図 10 にみ るように，カスケードに接続されたサイリス夕を同時 に導通して三相交流電源を短絡することなくマグネッ トの短絡回路を形成するモードである。 
秦了モ一ド制 御

Table 3. Mode control.

\begin{tabular}{|c|c|c|c|c|c|c|c|c|}
\hline$E-r$ & \multicolumn{2}{|c|}{ 電力系統之の充放䉓 } & \multicolumn{2}{|c|}{ 永久醃流 } & \multicolumn{2}{|c|}{ 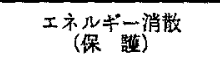 } & \multicolumn{2}{|c|}{ 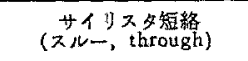 } \\
\hline 霫力骏搡器 & 並 列 & 直 列 & 並 列 & 㨁 列 & 亚 列 & 淔 列 & 亚 列 & 直 列 \\
\hline 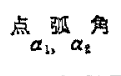 & $\alpha_{1}=\alpha_{2}$ & 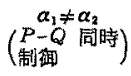 & 任 䈍 & 任 萑 & 任 意 & 任总 & 亦录ケート & ガスケード \\
\hline$S_{1}$ & 0 & 0 & 0 & 0 & $x$ & $x$ & $0 \times$ & $0 \times$ \\
\hline$S_{2}$ & $x$ & $x$ & 0 & 0 & 0 & 0 & $x$ & $x$ \\
\hline$S_{s a /} / S_{s b}$ & 0 & 0 & $x$ & $x$ & $x$ & $x$ & $0 \times$ & $0 \times$ \\
\hline$S_{4 a}$ & $x$ & 0 & $x$ & 0 & $x$ & 0 & $x$ & 0 \\
\hline$S_{6 b}$ & 0 & $x$ & 0 & $x$ & 0 & $x$ & 0 & $\mathrm{x}$ \\
\hline
\end{tabular}

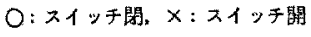

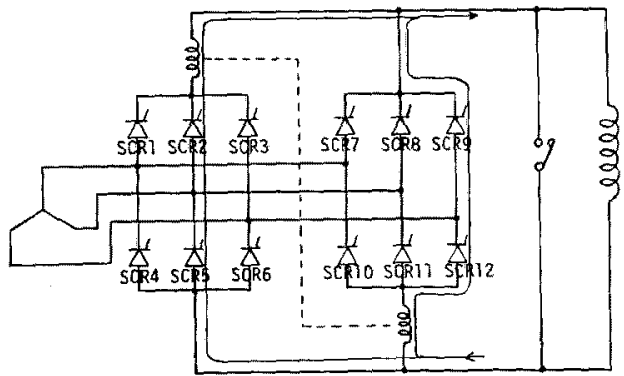

図 10 スルーモード

Fig. 10. Through mode.

充放電と永久電流またはエネルギー消散のモード間 の切り換えにおいて，交流電源は電生源であり，短絡 して仿ならないが、マグネットは電流源であり閏放し てはならない。スルーもードはこの相入れない条件を 満たすことができ，これらのモードの間に洀入するも のである。例えば，克電より永久電流運転のモードに 移るとき，充電モードの次にスルーモードを入れて， マグネット電流仙 (SCR 2-SCR 5) と (SCR 9-SCR 12) を経て通電を続けるが, 交流電源とは切り離されてい る。そののち $S_{2}$ を閉じて永久電流モードの運転に入 万。

〈6.2〉ママグネットの保讙電源回路およびマグ ネットに異常出態を生じたとき，マグネットのエネル

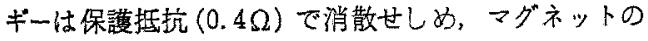
過電王による絶緣破罗や損稘，電源回路の亭故の抎大 を防止する。シーケンス制御装固は，サイリスタ変換 装圆の巽常, 交流側過電流およひマグネットのクウェ ンチなどの異常状態を監視しているが，これらの異常 琴象を検知すると，スルーモードを経でィルギー消 散そードに入るように主回路スイッチをシーケンス制 御する。

保讙抵抗は変換装置に亚列でなく直列に接続されて

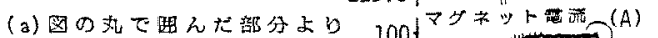
保譙槙にはいっている。

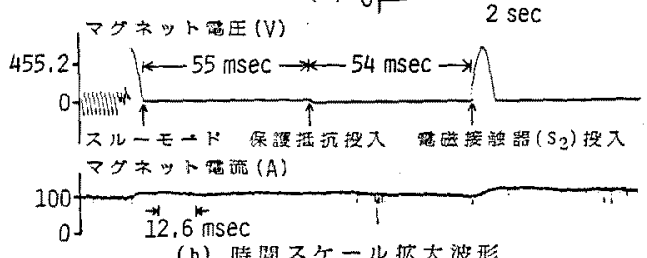

(b) 時咸不々一儿桩大波形

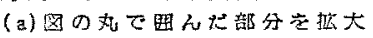

图 11 保难動作の実鈳結果

Fig. 11. Experimental results of the protecting $[$ action.

以る。てれは，スルーモードに就りるサイリス夕によ るマグネット短絡状態加ら， $S_{1}$ 開により保護抵抗が グネットに直列に接絸され，エネルギ一消散ができる ことをねらったものである。因 11 亿充電モードより エネルギー消散に至る過渡状態を示す。(b)図にるる ように, $55 \mathrm{~ms}$ の期閭のスルーモードに続き, $54 \mathrm{~ms}$

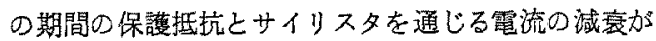
あり，次いで $S_{2}$ によりサイリス夕が短絡される。サ イリスタの電流が保持電流以下になるとサイリスタは オフ状態になるが，図 10 の2 個のブリッジ回路で並 列につながる2組のサイリスタのなかでオフ状態への 回復時間の相異があれば，困にみるような交流電王波 形が䍐われることがある。

これまでに数回のクウェンチ現象を生じたが，保譙 モードは確実に作動してマグネットの損傷には至って いない。

\section{7.むすひ}

20.5MJ パルスマグネットとその制御・保護システ

昭 $59-10$ 
ムについて述べた。民の結果は以下のように要約され 更。

(i) $0.5 \mathrm{MJ}$ パルスマグネットに执いては，液体 ヘリウム泠却通路を適切に設け，交流損失を低減する ような線材構成を行ない，更に洗線間にゆるみのない 処理を施した結果，高い電流密度 $\left(168 \mathrm{~A} / \mathrm{mm}^{2}\right)$ で安定 に通電でき，高速度 $(1,976 \mathrm{~A} / \mathrm{s})$ で最大電流 $(1,976 \mathrm{~A})$ まで斺磁できる性能を得た。

(ii）高い信頼性のむとで超電導マグネットを活用 するための超電導マグネットシステム技術碎立しな け圠ばならない。その原班となるシステムを $0.5 \mathrm{MJ}$ マグネットについて满成した。

（首）マグネットの電流を高速度・高精度で制御す る直接ディジタル制御系を構成し，状態ベクトルフィ ードバックを用いた最确制御により正確な電流制御特 性を得ている。

（iv）シーケンス制御装置により主スイッチの開閉 を制御し，モード切り換えを行なうシステムを構成し た。モードの切り換えを噻実に行なうために，切り換 えの中間に直流側と交流側を分醀するスルーモードを 設けて，マグネットの短絡においてす交流系統には短 絡回路を生じない上うにした。この結果，マグネット の異常現象汇おいてモード切り換えの組合せからなる 確夷な保護動作が行なわれている。

終りに，ご指導を踢わった本学超電導工学実験セン タ一前所長大石嘉雄名裳教授に厚く謝意审し上げ る。また，パスマグネットの䭫失の推定にご指導を 受けた電総研大西氏，マグネットの開発に尽力してい ただいた三菱電機 河村，佐藤，獭野，川日，東野，住

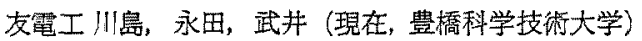
の各氏，ならびに大学院学生しして夷験に協力された 諳君に深い謝意を表する。

この研究には，文部省エネルギー特別研究「電気工 ネルギーの有効利用之高密度化に関する研究」の補助 を受けた。

(明和 58 年8月 15 日受付，同 59 年 5 月 28 日再受柇)

\section{文献}

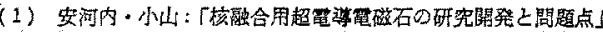
電学能 99, 731 (昭 54-8)

(2) M. Masuda, et al. : "Power System Stabilization by Superconducting Magnet Energy Storage", US-Japan Work. shop of Superconducting Magnet Energy Storage, p. 120, Oct., 19-23, University of Wisconsin, Madison (1981)

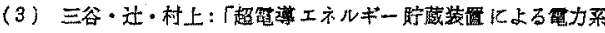

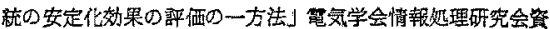

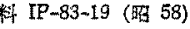

(4) K. Tsuji, T. Ise \& Y. Murakami: :A P-Q Simultaneous Control Scheme for SMES", US-Japan Workshop of Superconducting Magnet Energy Storage, p. 106 (1981)

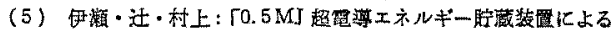

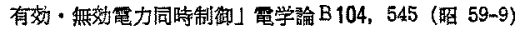

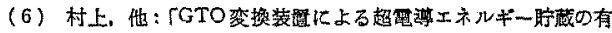
效無效電力制御」電気学会半導体管力变损研究会資料 SPC. 83-19 (明 58-8)

(7) S.H. Kim, C. I. Krieger, \& D.G. Mcgee: "Further Tests of the Argonne 3. 3MJ Pulsed Superconducting Coil and its Nonmetallic Cryostat", IEEE Trans. Magnetics, MAG-19, 3, 346 (1983)

(8) T. Satow, M. Iwamoto, K. Toyoda, T. Ogasawara, Y. Kubota, T. Makiura, K. Yasukochi, H. Momota, K. Sato, S. Yamada, K. Koyama \& T. Onishi: "Superconducting Poloidal Coils for the Reacting Plasma Project-Test Resuts of a Model Coil (RPC-I) at a $200 \mathrm{~T} / \mathrm{s}$ Pulsing rate and design of a new coil (RPC-II), ibid. MAG-19, 3, 1406 (1983-5)

(9) Y. Murakami, T. Okada, J. Yamamoto, Y. Inuishi, A Mitsuishi \& M. Nishimura : " $0.5 \mathrm{MJ}$ Superconducting Pulse Magnet for Energy Storage" ${ }^{\prime}$ ibid, MAG-17, 1, 505 (1981)

(10) T. Onishi, H. Takeishi, K. Komuro \& K. Koyama: "Experiment of Pulsed Superconductive Energy Storage", Proceedings of the International Symposium on Superconductive Energy Storage, p. 56 (1979)

(11) T. Satow, et al.: "Development' and Characteristics of 0.5 MJ Superconducting Magnet", ICEC-9, p. 309, Kobe (1982-5)

(12) H. Takei, et al. : "Metallugical and Electromagnetic Froperties of Supexconducting Cable for OSAKA Univ.'s 0.5 MJ Pulsed Magnet", ibid. p. 485 (1982-5)

(13）村上・谷口・平日・西村：「超䉓導マグネットの直接ディシ 夕儿制御」電学俭 B 102，4，203(昭 57-4)

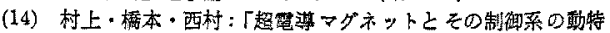
性推定」同上，102，3，129(昭 57-3)

(15) Y. Murakami, K. Kikuchi, K. Hashimoto, J. Yamamoto, T. Okada \& Y. Inuishi : "Dynamics and Controlled Characteristics of 0.5 MJ Pulsed Magnet", ICEC-9, p. 126 (1982-5)

(16) Y. Murakami, M. Sugita, H. Okuda, N. Ouchi, J. Yamamoto, T. Kinouchi, T. Okada \& Y, Iruishi : "0.5 MJ Pulsed Magnet with its Control and Cooling Systems", ibid. p. 130 (1982-5)

(17) H. Takeishi, T. Onishi, X. Komuro \& K. Koyama : "The Influence of Solder-filling on the AC Losses of Pulsed Superconducting Cables", Cryogenics. p. 509 (1982 10)

（18）高㰌：「システムと制微」第2 版下（昭 55）岩波弯店 